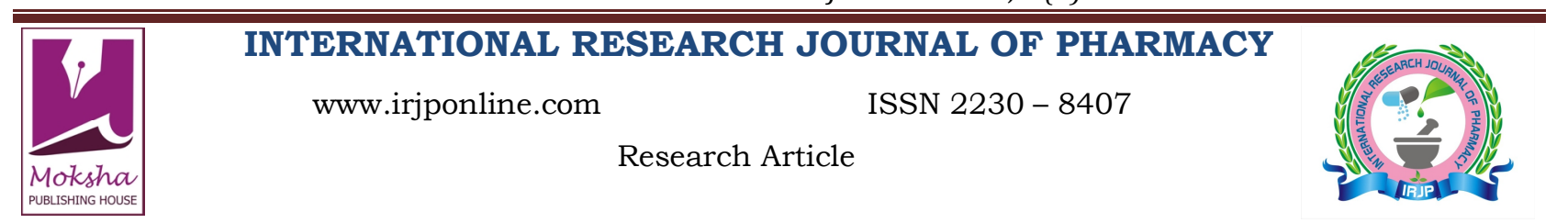

\title{
IN VIVO ANTI INFLAMMATORY AND ANTI ARTHRITIC ACTIVITY OF ETHANOLIC EXTRACT OF ASPARAGUS RACEMOSUS ROOTS
}

\author{
Suchita Mittal*, Praveen K. Dixit \\ Department of Pharmacology, Jaipur College of Pharmacy, Jaipur, Rajasthan, India \\ Email: pharmindia.mittal4@gmail.com
}

Article Received on: 27/02/13 Revised on: 08/03/13 Approved for publication: 11/04/13

DOI: $10.7897 / 2230-8407.04433$

IRJP is an official publication of Moksha Publishing House. Website: www.mokshaph.com

(C) All rights reserved.

\section{ABSTRACT}

The present study is aimed to appraise the anti-inflammatory and anti-arthritic activity of ethanolic extract of Asparagus racemosus roots belonging to family Liliaceae. Carrageenan is used to induce inflammation and Freund's Complete Adjuvant is used to induce arthritis. The result of this study revealed that Asparagus racemosus show potent effect on both the condition at a dose of $200 \mathrm{mg} / \mathrm{kg}$ and $400 \mathrm{mg} / \mathrm{kg}$ respectively.

Key Words: Asparagus racemosus, Anti-inflammatory, Anti-arthritis, Carrageenan.

\section{INTRODUCTION}

If infectious diseases are troubling the general population on one hand, the pace of modern life is adding to the woes of the middle class ${ }^{1}$. Numerous physiological and biochemical processes in the human body may produce oxygen-centered free radicals and other reactive oxygen species as by products. Overproduction of such free radicals can cause oxidative damage to biomolecules (e.g. lipids, proteins, DNA), eventually leading to many chronic diseases, such as atherosclerosis, cancer, diabetes, aging, and other degenerative diseases in human ${ }^{2}$.

When cells in the body are damaged by microbes, physical agents or chemical agents, the injury is in the form stress. The response to the stress of tissue damage is called as inflammation ${ }^{3}$. Inflammation is a complex process, which is frequently associated with pain and involves occurrences such as: the increase of vascular permeability, increase of protein denaturation and membrane alteration ${ }^{4}$. Inflammatory response is a series of well coordinated dynamic mechanism consisting of specific vascular, humoral and cellular events that is characterized by the movement of fluids, plasma and inflammatory leukocytes (neutrophils, eosinophils, basophils and macrophages) to the site of inflammation ${ }^{5}$. Lysosomal enzymes released during inflammation produce a variety of disorders which leads to the tissue injury by damaging the macromolecules and lipid peroxidation of membranes which are assumed to be responsible for certain pathological conditions as heart attacks, septic shocks and rheumatoid arthritis etc. The extra cellular activity of these enzymes is said to be related to acute or chronic inflammation ${ }^{6}$. Although rheumatism is one of the oldest known diseases of the mankind and affects a large percentage of population of the world ${ }^{7}$. The management of rheumatoid arthritis (RA) rests on several principles such as drug treatment, which comprises diseasemodifying anti rheumatic drugs (DMARDs) and also non-steroidal anti-inflammatory drugs and gluco corticoids (GCs), as well as nonpharmacological measures, such as physical, occupational and psychological therapeutic approaches, together may lead to therapeutic success ${ }^{8}$. Most of the anti-inflammatory drugs are steroidal or nonsteroidal anti-inflammatory drugs. Though they are very useful, they have a number of severe adverse effects such as gastrointestinal disturbances and body fat redistribution ${ }^{9}$. To overcome these problems the preparations from plant origin become important in modern medicine and widely prescribed in traditional medicinal systems ${ }^{10}$. Numerous types of herbs have been well recognised and catalogued by botanist from the high ranges of the Himalayan tract up to the sea-shores of Kanyakumari. According to WHO nearly $80 \%$ of the global population still rely upon the herbal drugs for their primary health care ${ }^{11}$. The present study was focused to evaluate the anti-arthritis and anti-inflammatory potentials of ethanolic extract of Asparagus racemosus roots by widely accepted methods.

\section{MATERIALS AND METHODS}

Collection of plant: The part of the plant (roots) has been collected from local market of Lucknow (U.P) and identified by the University of Rajasthan, Jaipur. After procurement, the roots were dried in shade and ground mechanically into a coarse powder and kept into an air-tight container for use in the study.

Preparation of extract: The powdered plant material was successively extracted using ethanol in a soxhlet extraction apparatus. The extract was concentrated and traces of the solvent were completely removed under reduced pressure and stored in vacuum desiccators for further use. The extract was named as ethanol extract of Asparagus racemosus (AREE).

Chemicals: Carrageenan and Freund's Complete Adjuvant were purchased from UGO Basil, Sigma Aldrich (USA) and the entire reagents used in the study were analytical grade.

Selection of Animals: Wistar rats (150-200 g) of either sex, procured from Jaipur College of Pharmacy, Jaipur, were used. Animals were housed at $25 \pm 1{ }^{\circ} \mathrm{C}$ and at standard environmental conditions ( $12 \mathrm{~h}$ light and $12 \mathrm{~h}$ dark cycle) in the institutional animal house. The animals were fed with standard pellet rodent diet and water was provided ad libitum. All the experiments were carried out between 09.00 am to $5.30 \mathrm{pm}$ and approved by Institutional Animal Ethical Committee of Jaipur College of Pharmacy, Jaipur. 
Pharmacological Study

Carrageenan induced inflammation: Carrageenan-induced rat paw oedema has been used for assessment of the antiinflammatory activity of many plant extracts ${ }^{12}$. The animals were divided into 5 groups of 6 animals each (one normal, one control, one standard and two test groups). Edema in the rats were induced by injection of $0.05 \mathrm{ml}$ of carrageenan (prepared as $1 \% \mathrm{w} / \mathrm{v}$ suspension in saline) locally injected into sub plantar region of the left hind paw of rats.

\section{Treatment Groups}

Normal: $1 \%$ aqueous solution of Tween 80 , p.o. Control: Carrageenan $+2 \%$ Tween $80(10 \mathrm{ml} / \mathrm{kg})$.

Standard: Carrageenan + Diclofenac sodium $(4 \mathrm{mg} / \mathrm{kg})$

Test group (Low dose): Carrageenan + AREE (200mg/kg)

Test group (High dose): Carrageenan + AREE (400mg/kg)

The extracts were administered orally into the rats 1 hour prior to carrageenan injection. Diclofenac sodium $(4 \mathrm{mg} / \mathrm{kg}$ ) was given to standard group. The volume of the paw was measured $1 \mathrm{~h}$ before the injection and at 1, 2, 3, 4, 5, 6 and 24 hrs after the injection of carrageenan. Edema was expressed as the increment in paw thickness due to carrageenan administration $^{13}$. The percentage inhibition of paw volume in extract treated groups was compared with control.

Reduction in the paw volume were compared with the vehicle treated controlled animals with that of the test groups and the anti-inflammatory activity were carried out on the basis of the percentage (\%) inhibition of edema. The percent inhibition of edema was calculated by using the formula ${ }^{14}$.

$\%$ inhibition of edema $=(\mathrm{Vc}-\mathrm{Vt} / \mathrm{Vc}) \times 100$

Where $\mathrm{Vt}=$ Paw volume in test group animals, $\mathrm{Vc}=\mathrm{Paw}$ volume in control group.

\section{Freund's Complete Adjuvant induced Arthritis}

Arthritis was induced by a single intra-dermal injection $(0.1$ $\mathrm{ml}$ ) of Complete Freund's adjuvant (CFA) containing $1.0 \mathrm{mg}$ dry heat-killed Mycobacterium tuberculosis per milliliter sterile paraffin oil into a foot pad of the left hind paw of rats $^{15}$. The animals were divided into 5 groups of 6 animals each (one normal, one control, one standard and two test groups).

\section{Treatment groups}

Normal: $1 \%$ aqueous solution of Tween 80

Control: FCA + $2 \%$ Tween $80(10 \mathrm{ml} / \mathrm{kg})$.

Standard: FCA + Dexamethasone $(5 \mathrm{mg} / \mathrm{kg})$

Test group (Low dose): FCA + AREE (200mg/kg)

Test group (High dose): FCA + AREE (400mg/kg)

The dosing of all the groups was started from day $12^{\text {th }}$ once daily orally. Various parameters i.e. body weight, joint diameter, paw volume, arthritic score, motor incordination, analgesic have been evaluated on day $0^{\text {th }}, 4^{\text {th }}, 7^{\text {th }}, 10^{\text {th }}, 12^{\text {th }}$, $14^{\text {th }}, 17^{\text {th }}, 19^{\text {th }}, 21^{\text {th }}$, and day $28^{\text {th }}$. On last day (day $28^{\text {th }}$ ), blood was withdrawn by retro-orbital puncture for assessment of hematological parameters i.e. WBC, RBC, Hb, ESR.

\section{Behavioral assessment}

Paw Volume

Paw volumes of both hind limbs were recorded on the day of FCA injection, and again measured on day $0^{\text {th }}$ till day $28^{\text {th }}$ using mercury plethysmometer ${ }^{18}$. The change in paw volume was measured as the difference between the final and initial paw volumes ${ }^{16}$.

\section{Joint Diameter}

Paw thickness was measured by compressing the joint by rotating the screw of micrometer screw gauge till the pain elicited as indicated by squeaking or leg withdrawal. The distance moved by the screw gauge was recorded ${ }^{17}$.

\section{Arthritic Score}

The arthritic severity in each paw was graded from 0 to 4: $0=$ paws with no swelling and focal redness.

$1=$ paws with swelling of finger joints.

$2=$ paws with mild swelling of ankle or wrist joints.

$3=$ paws with severe inflammation of the entire paw.

$4=$ paws with deformity or ankylosis.

Each paw was graded and the four scores were totalled so that the possible maximum score per rat was $16^{18}$.

Table.1: Effect of AREE on paw edema

\begin{tabular}{|c|c|c|c|c|c|c|}
\hline S. No. & $\begin{array}{c}\text { Time } \\
\text { (Hour) }\end{array}$ & Control & Normal & Standard & $\begin{array}{c}\text { AREE } \\
(200 \mathrm{mg} / \mathrm{kg})\end{array}$ & $\begin{array}{c}\text { AREE } \\
(400 \mathrm{mg} / \mathrm{kg})\end{array}$ \\
\hline 1. & 1 & $\begin{array}{l}0.2 \pm \\
0.00\end{array}$ & $0.00 \pm 0.000$ & $0.200 \pm 0.000$ & $\begin{array}{l}0.2 \pm \\
0.00\end{array}$ & $\begin{array}{l}0.2 \pm \\
0.00\end{array}$ \\
\hline 2. & 2 & $\begin{array}{l}0.4 \pm \\
0.00\end{array}$ & $0.00 \pm 0.000$ & $0.333 \pm 0.067$ & $\begin{array}{c}0.33 \pm \\
0.06\end{array}$ & $\begin{array}{l}0.2 \pm \\
0.00\end{array}$ \\
\hline 3. & 3 & $\begin{array}{c}0.53 \pm \\
0.06\end{array}$ & $0.00 \pm 0.000$ & $0.333 \pm 0.067$ & $\begin{array}{l}0.4 \pm \\
0.11\end{array}$ & $\begin{array}{l}0.4 \pm \\
0.00\end{array}$ \\
\hline 4. & 4 & $\begin{array}{l}0.6 \pm \\
0.00\end{array}$ & $0.00 \pm 0.000$ & $0.267 \pm 0.067^{* *}$ & $\begin{array}{l}0.33 \pm \\
0.06^{*}\end{array}$ & $\begin{array}{c}0.33 \pm \\
0.06^{* *}\end{array}$ \\
\hline 5. & 5 & $\begin{array}{c}0.53 \pm \\
0.06 \\
\end{array}$ & $0.00 \pm 0.000$ & $\begin{array}{c}0.067 \pm \\
0.067 * * *\end{array}$ & $\begin{array}{l}0.26 \pm \\
0.06 *\end{array}$ & $\begin{array}{c}0.26 \pm \\
0.06^{* *}\end{array}$ \\
\hline 6. & 6 & $\begin{array}{l}0.6 \pm \\
0.11\end{array}$ & $0.00 \pm 0.000$ & $\begin{array}{c}0.000 \pm \\
0.000^{* * *}\end{array}$ & $\begin{array}{c}0.2 \pm \\
0.00^{* * *}\end{array}$ & $\begin{array}{c}0.06 \pm \\
0.06 * * *\end{array}$ \\
\hline 7. & 24 & $\begin{array}{l}0.6 \pm \\
0.11\end{array}$ & $0.00 \pm 0.000$ & $\begin{array}{c}0.000 \pm \\
0.000^{* * *}\end{array}$ & $\begin{array}{c}0.2 \pm \\
0.00^{* * *}\end{array}$ & $\begin{array}{c}0.00 \pm \\
0006^{* * * *}\end{array}$ \\
\hline
\end{tabular}

Values were expressed Mean \pm SEM. ${ }^{*} \mathrm{P}<0.05 ; * * \mathrm{P}<0.01$ and $* * * \mathrm{P}<0.001$ significant as compared to control group animals. 
Suchita Mittal et al. Int. Res. J. Pharm. 2013, 4 (4)

Table.2: Effect of AREE on average body weight

\begin{tabular}{|c|c|c|c|c|c|c|}
\hline S.No. & Days & Control & Normal & Standard & $\begin{array}{c}\text { AREE } \\
(200 \mathrm{mg} / \mathrm{kg})\end{array}$ & $\begin{array}{c}\text { AREE } \\
(400 \mathrm{mg} / \mathrm{kg})\end{array}$ \\
\hline 1. & 12 & $\begin{array}{c}94.16 \pm \\
3.27\end{array}$ & $\begin{array}{c}101.66 \pm \\
13.017\end{array}$ & $\begin{array}{c}161.66 \pm \\
6.00\end{array}$ & $\begin{array}{c}75.00 \pm \\
0.000\end{array}$ & $\begin{array}{l}83.33 \pm \\
8.333\end{array}$ \\
\hline 2. & 14 & $\begin{array}{c}88.33 \pm \\
2.10\end{array}$ & $\begin{array}{c}108.33 \pm \\
8.333\end{array}$ & $\begin{array}{l}168.33 \pm \\
4.41 * * *\end{array}$ & $\begin{array}{c}90.00 \pm \\
5.773\end{array}$ & $\begin{array}{c}86.66 \pm \\
9.279\end{array}$ \\
\hline 3. & 17 & $\begin{array}{c}77.50 \pm \\
2.14\end{array}$ & $\begin{array}{c}108.33 \pm \\
8.333\end{array}$ & $\begin{array}{l}171.66 \pm \\
1.66 * * *\end{array}$ & $\begin{array}{c}106.66 \pm \\
6.666^{*}\end{array}$ & $\begin{array}{l}98.33 \pm \\
13.017\end{array}$ \\
\hline 4. & 19 & $\begin{array}{c}76.66 \pm \\
2.47\end{array}$ & $\begin{array}{c}108.33 \pm \\
8.333\end{array}$ & $\begin{array}{l}176.66 \pm \\
1.66 * * *\end{array}$ & $\begin{array}{l}116.66 \pm \\
3.333^{* *}\end{array}$ & $\begin{array}{l}103.33 \pm \\
14.813^{*}\end{array}$ \\
\hline 5. & 21 & $\begin{array}{c}72.50 \pm \\
1.11\end{array}$ & $\begin{array}{c}108.33 \pm \\
8.333\end{array}$ & $\begin{array}{l}178.33 \pm \\
1.66 * * *\end{array}$ & $\begin{array}{c}130.00 \pm \\
5.000^{* * *}\end{array}$ & $\begin{array}{c}128.33 \pm \\
11.666^{* * *}\end{array}$ \\
\hline 6. & 28 & $\begin{array}{c}72.50 \pm \\
1.11\end{array}$ & $\begin{array}{c}116.66 \pm \\
8.333\end{array}$ & $\begin{array}{l}188.33 \pm \\
3.33 * * *\end{array}$ & $\begin{array}{r}143.33 \pm \\
6.666^{* * *}\end{array}$ & $\begin{array}{c}133.33 \pm \\
8.333^{* * *}\end{array}$ \\
\hline
\end{tabular}

Values were expressed Mean \pm SEM. $* \mathrm{P}<0.05 ; * * \mathrm{P}<0.01$ and $* * * \mathrm{P}<0.001$ significant as compared to control group animals.

Table.3 Effect of AREE on average arthritic score

\begin{tabular}{|c|c|c|c|c|c|c|}
\hline S.No. & Days & Control & Normal & Standard & $\begin{array}{c}\text { AREE } \\
(200 \mathrm{mg} / \mathrm{kg})\end{array}$ & $\begin{array}{c}\text { AREE } \\
(400 \mathrm{mg} / \mathrm{kg})\end{array}$ \\
\hline 1. & 12 & $\begin{array}{l}2.00 \pm \\
0.365\end{array}$ & $\begin{array}{c}0.00 \pm \\
0.00\end{array}$ & $\begin{array}{l}2.00 \pm \\
0.000\end{array}$ & $\begin{array}{l}2.33 \pm \\
0.333\end{array}$ & $\begin{array}{l}2.66 \pm \\
0.333\end{array}$ \\
\hline 2. & 14 & $\begin{array}{l}1.83 \pm \\
0.166\end{array}$ & $\begin{array}{c}0.00 \pm \\
0.00\end{array}$ & $\begin{array}{l}1.66 \pm \\
0.333\end{array}$ & $\begin{array}{l}2.00 \pm \\
0.000\end{array}$ & $\begin{array}{l}2.33 \pm \\
0.333\end{array}$ \\
\hline 3. & 17 & $\begin{array}{l}1.83 \pm \\
0.166\end{array}$ & $\begin{array}{c}0.00 \pm \\
0.00\end{array}$ & $\begin{array}{c}0.00 \pm \\
0.000^{* * *}\end{array}$ & $\begin{array}{l}1.33 \pm \\
0.333\end{array}$ & $\begin{array}{c}1.00 \pm \\
0.333 *\end{array}$ \\
\hline 4. & 19 & $\begin{array}{l}2.16 \pm \\
0.307\end{array}$ & $\begin{array}{c}0.00 \pm \\
0.00\end{array}$ & $\begin{array}{c}0.00 \pm \\
0.000^{* * *}\end{array}$ & $\begin{array}{l}1.33 \pm \\
0.333\end{array}$ & $\begin{array}{c}1.00 \pm \\
0.333 *\end{array}$ \\
\hline 5. & 21 & $\begin{array}{l}2.33 \pm \\
0.210\end{array}$ & $\begin{array}{c}0.00 \pm \\
0.00\end{array}$ & $\begin{array}{c}0.00 \pm \\
0.000^{* * *}\end{array}$ & $\begin{array}{c}1.00 \pm \\
0.000^{* *}\end{array}$ & $\begin{array}{c}0.33 \pm \\
0.333^{* * *}\end{array}$ \\
\hline 6. & 28 & $\begin{array}{l}1.83 \pm \\
0.166\end{array}$ & $\begin{array}{c}0.00 \pm \\
0.00\end{array}$ & $\begin{array}{c}0.00 \pm \\
0.000^{* * *}\end{array}$ & $\begin{array}{c}0.66 \pm \\
0.333^{* * *}\end{array}$ & $\begin{array}{c}0.33 \pm \\
0.333^{* * *}\end{array}$ \\
\hline
\end{tabular}

Values were expressed Mean \pm SEM. $* \mathrm{P}<0.05 ; * * \mathrm{P}<0.01$ and $* * * \mathrm{P}<0.001$ significant as compared to control group animals.

Table.4 Effect of AREE on average paw volume

\begin{tabular}{|c|c|c|c|c|c|c|}
\hline S.No. & Days & Control & Normal & Standard & $\begin{array}{c}\text { AREE } \\
(200 \mathrm{mg} / \mathrm{kg})\end{array}$ & $\begin{array}{c}\text { AREE } \\
(400 \mathrm{mg} / \mathrm{kg})\end{array}$ \\
\hline 1. & 12 & $\begin{array}{c}0.46 \pm \\
0.04 \\
\end{array}$ & $\begin{array}{c}0.00 \pm \\
0.00\end{array}$ & $\begin{array}{l}0.40 \pm \\
0.115 \\
\end{array}$ & $\begin{array}{c}0.533 \pm \\
0.066 \\
\end{array}$ & $\begin{array}{c}0.667 \pm \\
0.067 \\
\end{array}$ \\
\hline 2. & 14 & $\begin{array}{c}0.50 \pm \\
0.0\end{array}$ & $\begin{array}{c}0.00 \pm \\
0.00\end{array}$ & $\begin{array}{l}0.33 \pm \\
0.066\end{array}$ & $\begin{array}{c}0.400 \pm \\
0.115\end{array}$ & $\begin{array}{l}0.46 \pm \\
0.066\end{array}$ \\
\hline 3. & 17 & $\begin{array}{c}0.50 \pm \\
0.04\end{array}$ & $\begin{array}{c}0.00 \pm \\
0.00\end{array}$ & $\begin{array}{c}0.20 \pm \\
0.000^{* *}\end{array}$ & $\begin{array}{c}0.333 \pm \\
0.066\end{array}$ & $\begin{array}{l}0.46 \pm \\
0.066\end{array}$ \\
\hline 4. & 19 & $\begin{array}{c}0.50 \pm \\
0.04 \\
\end{array}$ & $\begin{array}{c}0.00 \pm \\
0.00\end{array}$ & $\begin{array}{c}1.33 \pm \\
0.066^{* * *} \\
\end{array}$ & $\begin{array}{l}0.266 \pm \\
0.066^{*}\end{array}$ & $\begin{array}{l}0.266 \pm \\
0.066^{*}\end{array}$ \\
\hline 5. & 21 & $\begin{array}{c}0.46 \pm \\
0.04\end{array}$ & $\begin{array}{c}0.00 \pm \\
0.00\end{array}$ & $\begin{array}{c}0.06 \pm \\
0.066^{* * *}\end{array}$ & $\begin{array}{c}0.133 \pm \\
0.066^{* *}\end{array}$ & $\begin{array}{c}0.067 \pm \\
0.067 * * *\end{array}$ \\
\hline 6. & 28 & $\begin{array}{c}0.46 \pm \\
0.06 \\
\end{array}$ & $\begin{array}{c}0.00 \pm \\
0.00 \\
\end{array}$ & $\begin{array}{c}0.06 \pm \\
0.066^{* * *}\end{array}$ & $\begin{array}{c}0.133 \pm \\
0.066^{* *}\end{array}$ & $\begin{array}{c}0.067 \pm \\
0.067^{* * *}\end{array}$ \\
\hline
\end{tabular}

Values were expressed Mean \pm SEM. $* \mathrm{P}<0.05 ; * * \mathrm{P}<0.01$ and $* * * \mathrm{P}<0.001$ significant as compared to control group animals.

\section{Carrageenan induced Inflammation}

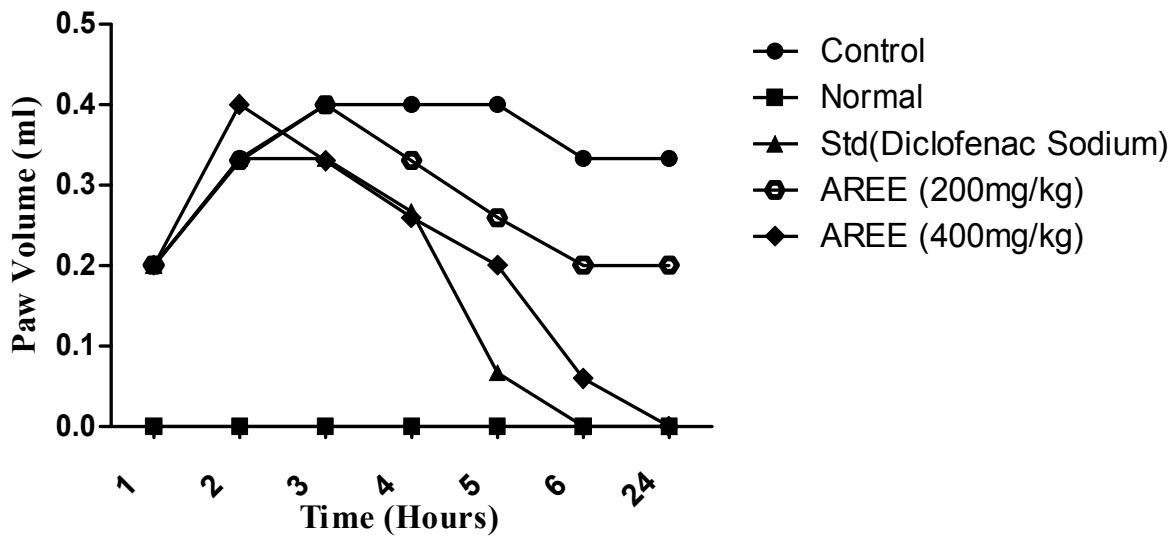

Figure 1: Effect of AREE on Carrageenan induced inflammation 


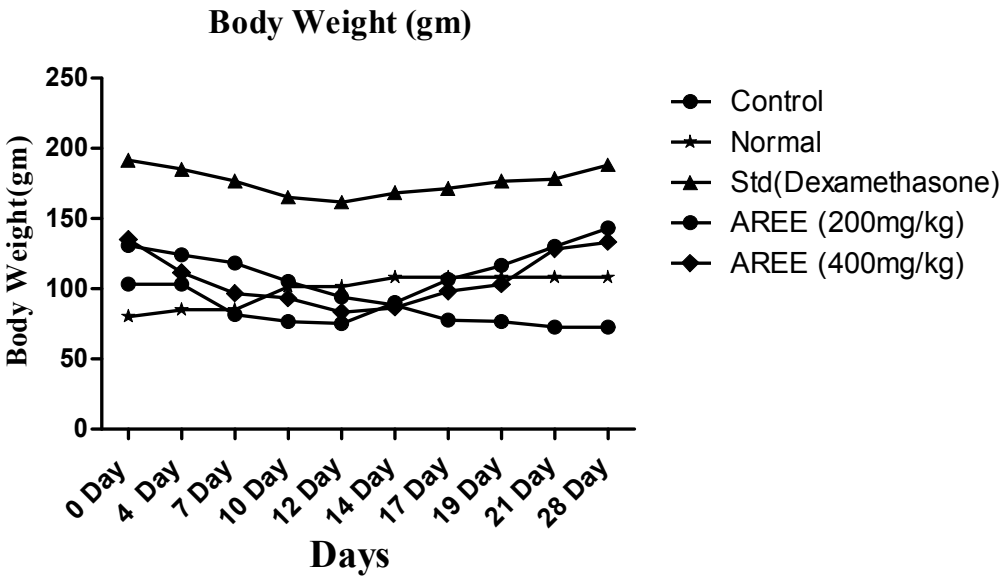

Figure 2: Effect of AREE on body weight

Arthritic Score

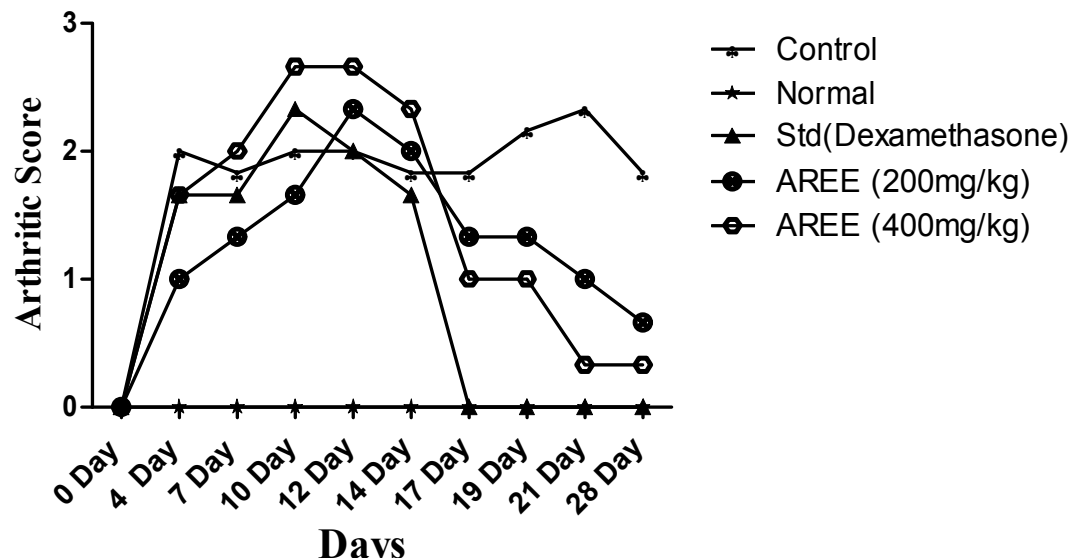

Figure 3: Effect of AREE on arthritic score

\section{Paw Volume}

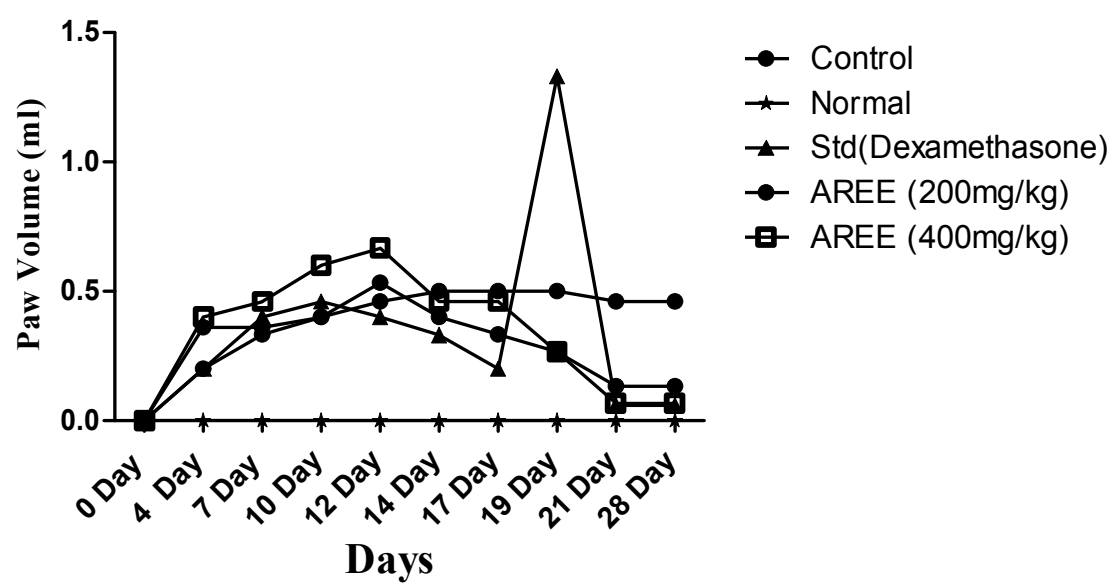

Figure 4: Effect of AREE on paw volume 


\section{RESULTS}

\section{Carrageenan induced inflammation}

Anti-inflammatory effect of AREE of roots was evaluated after subplantar injection of carrageenan in animals. The standard Diclofenac $(4 \mathrm{mg} / \mathrm{kg})$ showed significant and dosedependent decrease $(\mathrm{P}<0.01$ and $\mathrm{P}<0.001)$ in paw edema on $4^{\text {th }}, 5^{\text {th }}, 6^{\text {th }}$ and $24^{\text {th }}$ hours as compared to control group animals. Whereas treatment with AREE (400 mg/ $\mathrm{kg}$ ) showed significantly $(\mathrm{P}<0.01$ and $\mathrm{P}<0.001$ respectively) decrease in paw edema as compared to control group animals on $4^{\text {th }}$, $5^{\text {th }}, 6^{\text {th }}$ and $24^{\text {th }}$ hours. AREE $(200 \mathrm{mg} / \mathrm{kg})$ showed significantly decrease in paw edema as compared to control group animals $(\mathrm{P}<0.05, \mathrm{P}<0.01$ and $\mathrm{P}<0.001)$ on $4^{\text {th }}, 5^{\text {th }}$, $6^{\text {th }}$ and $24^{\text {th }}$ hours. (Table.1, Figure 1)

\section{FCA induced arthritis \\ Behavioral assessment \\ Effect of AREE on body weight}

Standard group animals showed significant increased in body weight $(\mathrm{P}<0.05, \mathrm{P}<0.01$ and $\mathrm{P}<0.001)$ from $14^{\text {th }}$ day to $28^{\text {th }}$ day as compared to the control group animals. Treatment with AREE $(400 \mathrm{mg} / \mathrm{kg})$ showed significant increase in body weight $(\mathrm{P}<0.05$, and $\mathrm{P}<0.001)$ as compared to control group animals from $19^{\text {th }}$ day to $28^{\text {th }}$ day. Treatment with AREE $(200 \mathrm{mg} / \mathrm{kg})$ showed significant increase in body weight $(\mathrm{P}<0.05, \mathrm{P}<0.01$ and $\mathrm{P}<0.01)$ as compared to control group animals from $17^{\text {th }}$ day to $28^{\text {th }}$ day. (Table.2, Figure 2)

\section{Effect of AREE on arthritic score}

All the groups of animals administered with FCA started showing signs of clinical inflammation in one or more hind paws, which was a biphasic response. The arthritic score was significantly increased from day $7^{\text {th }}$ to $12^{\text {th }}$ in control group animals which remained significantly increased till the end of the study i.e. up to $28^{\text {th }}$ day. Animals treated with Standard drug showed significant and dose dependant decreased in arthritic score $(\mathrm{P}<0.001)$ from day $17^{\text {th }}$ onward till the end of the study as compared to control group animals. Treatment with AREE (400 mg/kg) showed significant decreased in arthritic score $(\mathrm{P}<0.05,<0.001)$ as compare to control group animals from $17^{\text {th }}$ day to $28^{\text {th }}$ day. Treatment with AREE $(200 \mathrm{mg} / \mathrm{kg})$ showed significant decreased in arthritic score $(\mathrm{P}<0.01$ and $\mathrm{P}<0.001)$ as compare to control group animals from $21^{\text {th }}$ day to $28^{\text {th }}$ day. (Table. 3, Figure 3)

\section{Effect of AREE on paw volume}

Standard group animals showed significant decrease in paw volume $(\mathrm{P}<0.01$ and $\mathrm{P}<0.001) 17^{\text {th }}$ day to $28^{\text {th }}$ day as compared to the control group animals. Treatment with AREE $(400 \mathrm{mg} / \mathrm{kg})$ showed significant decreased in paw volume $(\mathrm{P}<0.05$, and $\mathrm{P}<0.001)$ as compare to control group animals from $19^{\text {th }}$ day to $28^{\text {th }}$ day. Treatment with AREE $(200 \mathrm{mg} / \mathrm{kg})$ showed significant decreased in paw volume $(\mathrm{P}<0.01, \mathrm{P}<0.001)$ as compare to control group animals from $19^{\text {th }}$ day to $28^{\text {th }}$ day. (Table. 4, Figure 4)

\section{DISCUSSION}

\section{Carrageenan induced inflammation:}

The primary phase of edema has been attributed to the release of histamine and serotonin; the edema maintaining during the plateaue phase, attribute to kinin like substances and the secondary accelerating phase of swelling is attributed to the release of prostaglandin ${ }^{19}$. Mediators like leukotriene, prostaglandins, PAF and cytokines are reported to be responsible for the immediate hypersensitivity reaction, but it was observed that enhanced vascular permeability and leukocyte infiltration at the sites of allergen challenge $e^{20}$.

\section{FCA induced arthritis}

The development of adjuvant-induced arthritis in the rat can be divided into three phases, just like human rheumatoid arthritis, starting with the induction phase without evidence of synovitis, followed by early synovitis, and finally late synovitis with progressive joint destruction ${ }^{21}$. Inhibition of COX-2 activity also modulated local and systemic cytokine production in arthritic rats. The development of arthritis was associated with increased levels of TNF- $\alpha$ and IL- 6 mRNAs in affected paws and systemic IL-6 production. Both cytokines have been shown to be produced spontaneously by rheumatoid arthritis synovial cells ${ }^{22}$.

\section{CONCLUSION}

Treatment with ethanolic extract of Asparagus racemosus (200 and $400 \mathrm{mg} / \mathrm{kg}$, p.o.) showed maximum reduction in paw volume as compared to vehicle treated animals in carrageenan induced rat paw edema. A significant increase in body weight, reduction in paw volume of both hind legs and reduction in total arthritic score were observed in FCA induced arthritis in rats. All these results thus envisage that the drug provide pharmacological rationale for the traditional use of the drug against inflammatory disorders such as rheumatoid arthritis.

\section{REFERENCES}

1. Ashwini $\mathrm{M}$, Lather $\mathrm{N}$, Bole $\mathrm{S}$, Vedamutrhy $\mathrm{AB}$, Balu $\mathrm{S}$. In vitro antioxidant and anti inflammatory activity of Coccinia grandis. International Journal of Pharmacy and Pharmaceutical Sciences 2012; 4(3): 239-242.

2. Chippada SC, Vangalapati M. Antioxidant, an anti-inflammatory and anti-arthritic activity of Centella asiatica extracts. Journal of Chemical, Biological and Physical Sciences 2011; 1(2): 260-269.

3. Adarsh Verma M, Ajay Kumar P, Kavitha D, Anurag KB. Anti denaturation and antioxidant activities of Annona cherimola in-vitro. International Journal of Pharma and Bio Sciences 2011; 2(2): 1-6.

4. Leelaprakash G, Dass SM. Invitro anti-inflammatory activity of methanol extract of Enicostemma axillare. International Journal of Drug Development \& Research 2011; 3(3): 189-196.

5. Gupta V, Chauhan S, Prakash A, Mathur A. Evaluation of in vitro and invivo anti-inflammatory activities of Parthenium camphora. Recent Research in Science and Technology 2013; 5(1): 33-39.

6. Deattu N, Narayanan N, Suseela L. Evaluation of Anti-Inflammatory and Antioxidant Activities of Polyherbal Extract by In Vitro Methods. Research Journal of Pharmaceutical, Biological and Chemical Sciences. 2012; 3(4): 727-732.

7. Shah Biren N, Nayak BS, Seth AK, Jalalpure SS, Patel KN, Patel MA and Mishra AD. Search for medicinal plants as a source of antiinflammatory and anti-arthritic agents - A review. Pharmacognosy Magazine 2006; 2(6): 77-86.

8. Kumar S, Vivek Kumar R. Invitro antiarthritic activity of isolated fractions from methanolic extract of Asystasia dalzelliana leaves. Asian Journal of Pharmaceutical and Clinical Research 2011; 4(3): 52-53.

9. Ajay Kumar .P, Adarsh Verma .M, Kavitha. D, Kranthi Kumar.A, Anurag KA. In-vitro antioxidant and antiinflammatory activities of Erythrina indica bark. International Journal of Pharmaceutical Sciences Review and Research 2010; 5(3): 181-184.

10. Bhadoriya SS, Mishra V, Raut S, Ganeshpurkar A, Jain SK. AntiInflammatory and Antinociceptive Activities of a Hydroethanolic Extract of Tamarindus indica Leaves. Scientia Pharmaceutica 2012; 80: 685-700. http://dx.doi.org/10.3797/scipharm.1110-09

11. Dixit Praveen K, Mittal S. A Comprehensive Review on Herbal Remedies of Diuretic Potential. International Journal of Research in Pharmacy and Science 2013; 3(1), 41-51.

12. Ibrahim AY, El-GengaIHI SE, Motawea HM, Sleem AA. AntiInflammatory Activity of Salvadora persica L. against Carrageenan Induced Paw Oedema in Rat Relevant to Inflammatory Cytokines. Notulae Scientia Biologicae 2011; 3(4):22-28.

13. Kumar V, Bhat ZA, Kumar D, Khan NA, Chashoo IA, Shah MY. Evaluation of anti-inflammatory potential of petal extracts of Crocus 
sativus "cashmerianus". International Journal of Phytopharmacology 2012; 3(1): 27-31.

14. Paramaguru, R., Jagadeeshwar, K., Kumar, C.B. M., and Raj, N. A. V., "Evaluation of anti-inflammatory activity on the leaves of Filicium decipiens in experimental animal models", Journal of Chemical and Pharmaceutical Research 2011; 3(3): 243-247.

15. Mishra NK, Bstia S, Mishra G, Chowdary KA, Patra S. Anti-arthritic activity of Glycyrrhiza glabra, Boswellia serrata and their synergistic activity in combined formulation studied in freund's adjuvant induced arthritic rats. J Pharm Educ Res 2011; 2(2): 92-98.

16. Mali SM, Sinnathambi A, Kapase CU, Bodhankar SL, Mahadik KR. Anti-arthritic activity of standardised extract of Phyllanthus amarus in Freund's complete adjuvant induced arthritis. Biomedicine and Aging Pathology2011;1:185-190.http://dx.doi.org/10.1016/j.biomag .2011 .09 .004

17. Otari KV, Shete RV, Upasani CD, Adak VS, Bagade MY .and Harpalani AN. Evaluation of Anti-inflammatory and anti-arthritic activities of ethanolic extract of Vernonia anthelmintica seeds. Journal of Cell and Tissue Research 2010; 10(2): 2269-2280.

18. Panchal AH, Patel RK, Bhandari A. Anti-arthritic and synergetic activity of Wedelia calendulacea L. with methotrexate in adjuvant induced arthritis with cardioprotective activity in rat. Pharmacologyonline 2011; 3: $175-187$.
19. Gupta S, Raghuvanshi M and Jain D. Comparative Studies on AntiInflammatory Activity of Coriandrum Sativum, Datura Stramonium and Azadirachta Indica. Asian J. Exp. Biol. Sci 2010; 1(1):151-154.

20. Vijayalakshmi A, Ravichandiran V, Jayakumari S, Malarkodi Velraj and Nirmala S. Anti-anaphylactic and Anti-inflammatory Activities of AFPA from the Root Bark of Plumeria acutifolia Poir. Indian Journal of Pharmaceutical Education and Research 2011; 45(4): 339-345.

21. Kyei S, Koffuor GA, Boampong JN. Antiarthritic effect of aqueous and ethanolic leaf extracts of Pistia stratiotes in adjuvant-induced arthritis in Sprague-Dawley rats. Journal of Experimental Pharmacology 2012; 4: 41-51.

22. Anderson GD, Hauser SD, McGarity KL, Bremer ME, Isakson PC and Gregory SA. Selective Inhibition of Cyclooxygenase (COX)-2 Reverses Inflammation and Expression of COX-2 and Interleukin 6 in Rat Adjuvant Arthritis. J. Clin. Invest 1996; 97(11): 2672-2679. http://dx.doi.org/10.1172/JCI1 18717

Cite this article as:

Suchita Mittal, Praveen K. Dixit. In-vivo anti-inflammatory and anti-arthritic activity of ethanolic extract of Asparagus racemosus roots. Int. Res. J. Pharm. 2013; 4(4):167-172 